this knowledge is evidently needed to identify all hazards and to become alert to the critical control points from which the HACCP system evolves. Food-services staff from higher socioeconomic status, those who are younger, and those who have attended educational courses have a higher level of knowledge about pathogens associated with foods or about the proper temperature for food storage. The findings about educational courses is in absolute accordance with other studies that have assessed the effectiveness of food hygiene and HACCP training. ${ }^{12,20,21}$

A generally positive attitude toward correct handling of food, safe storage practices, and cross-contamination control was more likely to be found among older foodservices staff and in respondents working in small hospitals, since those working in hospitals with less than 150 beds tended to be more careful in applying food-hygiene practices. All food-services staff should be aware that high standards of personal hygiene, such as effective hand washing and using gloves, are of paramount importance in terms of preventing food contamination and further in preventing the spread of infectious diseases. This study highlights the correlation of age, as well as the adherence of the HACCP model, with the regular use of gloves. This correlation of age with increased care may be explained by an inference that younger food-services staff are more likely to be careful and more highly motivated to avoid risky practices than older personnel who may have excessive confidence due to their working experience and did not deign to use gloves.

In conclusion, the information gathered from this study suggests the necessity for full implementation of, and adherence to, the HACCP system and for better infection control policies through a rigorous training program, including courses on health education on food safety and hygiene for all staff involved in hospital food services.

\section{REFERENCES}

1. Barrie D. The provision of food and catering services in hospital. J Hosp Infect 1996;33:13-33.

2. Jay LS, Comar D, Govenlock LD. A video study of Australian domestic food-handling practices. J Food Prot 1999;62:1285-1296.
3. Shapiro R, Ackers ML, Lance S, Rabbani M, Schaefer L, Daugherty J, et al. Salmonella Thompson associated with improper handling of roast beef at a restaurant in Sioux Falls, South Dakota. J Food Prot 1999;62:118-122.

4. Ehiri JE, Morris GP. Food safety control strategies: a critical review of traditional approaches. International Journal of Environmental Health Research 1994;4:254-263.

5. Mortlock MP, Peters AC, Griffith CJ. Food hygiene and Hazard Analysis Critical Control Point in the United Kingdom food industry: practices, perceptions, and attitudes. J Food Prot 1999;62:786-792.

6. Gazetta Ufficiale della Repubblica Italiana. Decreto Legislativo n.155 del 26.5.1997. Attuazione delle direttive 93/43/CEE e 96/3/CE concernenti l'igiene dei prodotti alimentari. G.U. n.136 del 13.6.1997. Roma, Italy;1997.

7. Guzewich JJ. Statewide implementation of a HACCP food service regulatory program. Journal of Environmental Health 1986;49:148152.

8. Smith JL. Foodborne infections during pregnancy. J Food Prot $1999 ; 62: 818-829$

9. Dryden MS, Keyworth N, Gabb R, Stein K. Asymptomatic foodhandlers as the source of nosocomial salmonellosis. J Hosp Infect 1994;28:195-208.

10. Lo SV, Connolly AM, Palmer SR, Wright D, Thomas PD, Joynson D. The role of the pre-symptomatic food handler in a common source outbreak of food-borne SRSV gastroenteritis in a group of hospitals. Epidemiol Infect 1994;113:513-521.

11. Maguire H, Pharoah P, Walsh B, Davison C, Barrie D, Threlfall EJ, et al. Hospital outbreak of Salmonella virchow possibly associated with a food handler. J Hosp Infect 2000;44:261-266.

12. Angelillo IF, Viggiani NMA, Rizzo L, Bianco A. Food handlers and foodborne diseases: knowledge, attitudes, and reported behavior in Italy. $J$ Food Prot 2000;63:381-385.

13. Altekruse SF, Street DA, Fein SB, Levy AS. Consumer knowledge of foodborne microbial hazards and food-handling practices. I Food Prot $1996 ; 59: 287-294$

14. Fein SB, Lin CTJ, Levy AS. Foodborne illness: perceptions, experience, and preventive behaviors in the United States. J Food Prot 1995;58:1405-1411.

15. Angelillo IF, Foresta MR, Scozzafava C, Pavia M. Consumers and foodborne diseases: knowledge, attitudes, and reported behavior in one region of Italy. Int J Food Microbiol 2001;64:161-166.

16. Istituto Nazionale di Statistica (ISTAT). Statistiche della Sanità. Anno 1997. Roma, Italy: ISTAT; 2000.

17. Hosmer DW, Lemeshow S. Applied Logistic Regression. New York, NY: Wiley \& Sons; 1989.

18. Richards J, Parr E, Riseborough P. Hospital food hygiene: the application of Hazard Analysis Critical Control Points to conventional hospital catering. J Hosp Infect 1993;24:273-282.

19. Codex Alimentarius Commission. Joint FAO/WHO Food Standards Programme. Food Hygiene. Basic Texts. Roma, Italy: FAO/WHO; 1999.

20. Cunningham CJ. A survey of the attitudes and perceptions of foodservice operators in the Hamilton-Wentworth region. Can J Public Health 1993;84:107-111.

21. Howes M, McEwen S, Griffiths M, Harris L. Food handler certification by home study, measuring changes in knowledge and behavior. Dairy Food and Environmental Sanitation 1996;16:737-744.

\title{
CDC Issues Infection Control Guidelines for Hemodialysis Centers
}

\section{Gina Pugliese, RN, MS Martin S. Favero, PhD}

The $\mathrm{CDC}$ recently released guidelines for preventing infection transmission among chronic hemodialysis patients. They contain updates on preventing antimicrobial resistance in the hemodialy- sis setting, as well as guidance on routine serological testing and immunization, surveillance, and training and education. The CDC has planned a mailing to all hemodialysis centers in the US that will include a copy of these guidelines and laminated posters, "At a Glance," that summarize the guidelines. These guidelines emphasize the need for hepatitis $B$ vacci- nation and specifically note that epidemiological investigations have indicated substantial deficiencies in recommended infection control practices, including failure to vaccinate patients against hepatitis $B$.

FROM: Recommendations for preventing transmission of infections among chronic hemodialysis patients. $M M W R$ 2001;50(RR 05):1-43. 